\title{
Depchopatbology.
}

\section{PSYCHONEUROSES AND PSYCHOSES.}

[25] A study of primary somatic factors in compulsive and obsessive neurosis.-L. Pierce Clark. Internat. Jour. of Psycho-analysis, 1920, ii, 150.

The writer finds that in many cases of compulsive and obsessive neurosis there is some somatic defect of instinct, such as tone deafness, colour blindness, inability to appreciate rhythm, or incapability of graceful gesture and movement. The fault is such as to prevent the individual from dispossessing the dominance of the ego-consciousness and allowing the free and unconscious externalization of the libido or desire-trend to fixate upon an object love or some field of interest. The neurosis, starting as a species of pernicious emotional repressions, soon undergoes, as the child grows up, a distinctive symbolization of the original fault and its conflicts. As a result of the neurosis many compulsives are deprived of normal associations and adjustments to the home, school, or playground; not a few, too, seem to have an inherently defective inaptitude to take up friendships or social life. Cases are quoted in which the patients suffering from this type of neurosis showed this psychobiologic inferiority of instincts, and where a knowledge of the conflict enabled a better adjustment to be made, with an amelioration of the symptoms. (In a footnote the Editor remarks that the symptoms mentioned by Dr. Clark would be considered by other psychopathologists to belong to anxiety-hysteria.) The writer emphasizes the importance of the necessity, for those who train children, to strive to cultivate every trait of emotional expression to the utmost, not alone that the individual may escape neurosis, but that it may start its life work with as few emotional and social handicaps as possible. All compulsive neurotics need to be encouraged in their efforts to take up some form of work or play that enables them to make good the innate faults of childhood and to re-educate themselves in this lack of early training.

C. W. Forsyth.

[26] The future of Service patients in mental hospitals.-WILLIAM Robinson. Jour. of Ment. Sci., 1921, lxvii, 40.

THE paper consists of an analysis of the cases of 140 Service patients in mental hospitals from the points of view of the etiology, the type of mental alienation, and the prognosis. The author 'states at the commencement that the public only imperfectly appreciates the true factors in the causation of the mental disorder, the varieties of psychosis encountered, and the prognosis; while trouble is always arising with the relatives in regard to the presence of Service patients in asylums and the failure to adopt certain methods of treatment to which prominence has lately been given by the Press.

He summarizes his conclusions, from which the following may be abstracted. A large percentage of Service patients have been sent to mental hospitals, after prolonged treatment in military hospitals, because 
they were considered incurable, and these patients are not of the type which can be cured by suggestion, psychotherapeutic conversations, hypnotism, or psycho-analysis. The mental condition of Service patients is such that special institutional treatment is necessary, for the welfare of the patients and the safety of others. As a class the Service patients have replaced the pre-war class of chronic mental cases, and in the former the history of hereditary instability and criminality is more frequent, while the incidence of a!cohol and syphilis as causative factors is unusually great.

The author concludes that it is impossible to arrive at any other opinion than that the Service patients would, as regards the majority, have been patients in mental hospitals sooner or later had there been no. war. As regards the minority, they would probably have constituted the pre-war group of waifs and strays, and formed the population of the casual wards of workhouses and the inhabitants of the prisons. He excuses himself for laying stress on facts which are within the expe.ience of the majority of his readers, on the grounds that the public is disposed to regard the Service patient as one who is curable and who ought to be cured, and that the statement that the cases are incurable is likely to lead to accusations from laymen of prejudgement and unwillingness to resort to recently advocated methods of treatment when old ones are ineffective.

Gas neurosis syndrome.-H. S. Hulbert. Amer. Jour. Insan., 1920 , lxvii, 213.

This is said to be similar to the non-concussion type of so-called shell shock, and is found in those who have been exposed to gas warfare. The symptoms are various degrees of physical movements related to altered or increased respiration, anxiety, altered consciousness, and involuntary motor movements. If recognized early, suitable treatment will cause recovery. Its severity is not in proportion to the organic damage from being gassed, but is in proportion to the make-up and military maladjustment of the individuals affected.

C. Stanford Read.

[28] A psycho-analytic study of manic-depressive psychoses.-Lucile. Dooley. Psycho-analytic Rev., 1921, viii, 38 (continued).

THIs study was undertaken primarily to determine whether or not psychoanalysis could be applied to the severe cases with beneficial results, and also to trace the symptoms back to phases of character development and to the specific crises in the lives of the patients where the arrest of emotional growth occurred. Nothing new in the psychology of the manic is here found, but there is confirmation of the view that this psychosis is a result of mental or emotional conflicts and repression, being of the compensatory type. The manic in his excitement speaks out quite frankly the wish that is kept out of even his secret conscious thought at other times. This disorder cannot be attacked at present by the psycho-analyst with the same hopeful and free spirit which he brings to the psychoneuroses or even to schizophrenia. In the depressed phase the patient may be inaccessible from inability to bring his own thoughts to bear on the problems, 
while in the manic phase his distractibility makes true analysis impossible, though the content of his speech may be used later for this purpose. In the normal periods the thoughts and feelings of the disturbed period are repressed, and a powerful resistance is encountered to recalling them. The personality of the manic-depressive also presents an obstacle. Those who have frequent manic attacks tend to get the upper hand of the analyst, and, though the transference seems good, the analyst is only an appendage to the greatly inflated ego. With the other type it is difficult to get them to make much effort, and as the conflicts are so deep-seated there is danger in meddling with the repressions. A suicide in a depressed patient, even a homicide in a manic, may be the result of incautious delvings into his inner life. The analyses of three cases are then given at some length.

\section{Stanford Read.}

An analysis of suicidal attempts.-Lawson G. Lowny. Jour. Nerv. and Ment. Dis., 1920, lii, 473.

THE author analyzes 46 attempts at suicide, and finds that 16 were cases of dementia præcox, 9 of manic-depressive insanity, 5 of psychopathic personality, 3 of psychoneurosis, 13 various. The direct causes of the attempt in 14 were depression; in 7, direction of hallucination or delusion ; in 6 , to escape persecution; in 7, to escape physical or mental disease or social unhappiness. The methods chosen in order of frequency were : cutting throat or artery, gas, poison, drowning, hanging, jumping from a height, swallowing foreign bodies, strangulation, shooting, and setting fire to clothing. All the cases were insane, psychopathic, or acutely alcoholic at the time of attempt. Normal people occasionally commit or attempt suicide.

R. G. Gordon.

A recurrent dream, a precursor of senile dementia.-Charles W. Burr. Amer. Jour. Insan., 1921, lxvii, 409.

THis is the report of a case of a man who, while seemingly in good health, though really in the prodromal stage of senile dementia, repeatedly dreamed he was suffering from melancholia, and in the dream described his agony of mind to his long-dead mother, and begged her sympathy and help. After an analysis of the patient's life history, the writer gives his explanation of the genesis of the dream as follows. All through the patient's mature life he had the fear of a mental breakdown, though he was not willing to admit it. The fear became so great that if anything stimulated his cortical cells during sleep they worked on what, during waking hours, obsessed him. Any Freudian interpretation is regarded as unnecessary and put out of court. It is pertinently asked whether many persons approaching a mental breakdown, preceded by a long prodromal period during which forebodings of evil are present, have a similar experience, and whether a physician's knowledge of it would not be of use in prognosis and in starting early treatment.

C. Stanford Read. 
[31] Parole system and its relation to occupational therapy.-A. J. Rosanoff and T. S. Cusack. Amer. Jour. Insan., 1920, lxvii, 149.

UNDER average conditions in state hospitals it is possible to increase paroles to hitherto unrealized numbers, with benefit to all concerned. The need for institutional care occurs only under circumstances which give rise to serious social maladjustment. Through inertia and other factors, patients are often held for years or life in the absence of external initiative. In the New York State Hospital service the growth of the parole system has been marked during the last decade. In 1911 the average daily number on parole was 2.5 per cent, in 19185.4 per cent, while in the Manhattan State Hospital it was then 8 per cent. In another state hospital a special survey to seek out those suitable for parole resulted, in 1920, in an increase there to 10.7 per cent. The authors see no reason why a percentage of 20 should not be reached and maintained. Active opposition is met with from physicians, nurses, and attendants to the parole of working patients. Extramural employment should be found for these cases, and they should be visited regularly by social workers. It is found that the removal of working patients resulted in the others receiving better oversight. Occupational therapy is then discussed. The important question of the selection of patients for parole is dwelt on, and it is stated that it seems impossible to predict for certain whether a given patient will get along well outside or not, and an actual trial of parole affords the most trustworthy means of judging. Other details of the system, including the essential factor of a well-organized social-service department, conclude a suggestive article.

C. Stanford Read.

\section{PSYCHOLOGY.}

[32] Emotions and instincts.-H. C. Link. Amer. Jour. Psychol., 1921, xxxii, 134.

THE article is a critical appreciation of the various attempts to identify the instincts with the emotions. After a brief discussion of the character of that identity as outlined by James, Sherrington, Cannon, and McDougall, the writer concludes that it is not possible to demonstrate by physiological methods upon animals the connection between emotions and bodily activities. Watson's work is favourably quoted as obviating the philosophic difficulties involved in earlier theories.

The author passes to a criticism of McDougall's attempt to classify the activities of life as developed from seven primary instincts. He points out the inadequacy of his two criteria of the primary instincts, but commends McDougall's analysis as an attempt to account for the dynamic nature of instinct by means of the emotive forces, the failure of their classification not impairing their validity as factors in the energy of behaviour.

He concludes by deprecating attempts to identify instincts with arbitrary groups of emotions, and emphasizes the highly speculative character of the conclusions drawn in this department of work.

R. Dansie. 